\title{
Impact of Discharged Process Wastewater from an Oil Refinery on the Physicochemical Quality of a Receiving Waterbody in Rivers State, Nigeria
}

\author{
${ }^{1}$ Marcus, A C and ${ }^{2}$ Ekpete, O A \\ Department of Chemistry, Ignatius Ajuru University of Education, P.M.B. 5047, Rumuolumeni, Port Harcourt, \\ Nigeria
}

\begin{abstract}
The impact of an oil refinery process wastewater on the levels of mercury, lead, nickel, vanadium and cadmium in water and the associated sediment were investigated in order to determine the physicochemical quality of the receiving water. Samples were collected at two-monthly intervals from ten locations for a period of one year. Trace metals samples were prepared by acid digestion using 1:3:1 mixture of $\mathrm{HClO}_{4}, \mathrm{HNO}_{3}$ and $\mathrm{H}_{2} \mathrm{SO}_{4}$ acids and those in water by solvent extraction using ammonium pyrrolidine dithiocarbamate (APDC) and methyl isobutyl ketone (MIBK). Buck scientific model 200A Atomic Absorption Spectrophotometer and airacetylene flame were used for the analyses, except for mercury which was by cold vapour technique using sodium borohydride in a mercury kit. Organic matter content was determined by the method of Walkey and Black. River water and the process wastewater quality parameters were determined using appropriate meters and various standard methods. The results of trace metals analyses in water with mean concentrations (ppb) were: $\mathrm{Hg}$ (BDL); $\mathrm{Pb}$ (21.66 \pm 11.65$) ; \mathrm{Ni}(38.84 \pm 32.15) ; \mathrm{V}(0.15 \pm 0.29)$ and $\mathrm{Cd}(4.45 \pm 2.43)$, while those of sediment (ppm, dry weight) and organic matter (\%) were as follows: $\mathrm{Hg}(0.273 \pm 0.016) ; \mathrm{Pb}(23.218 \pm 13.427)$; $\mathrm{Ni}(57.194 \pm 16.929) ; \mathrm{TOC}(1.135 \pm 0.401)$ and TOM $(1.990 \pm 0.703)$. These results revealed largely anthropogenic trace metal enrichment by organic loading most likely from land-driven waste brought in by runoff water and industrial wastes. Phosphate, which is particularly highest in the process wastewater, implicates the Port Harcourt refinery as an important source of this anion. The mean level of Ni in sediment (57.19 ppm) exceeded acceptable limits for sediment quality in Netherlands, and those of $\mathrm{Pb}$ and $\mathrm{Cd}$ in water also surpassed the background limits of <1.0-7.0) ppb for Pb and <0.2-2.8 ppb set by USA EPA for marine/brackish and freshwater.
\end{abstract}

Keywords: refinery process wastewater, trace metals, anthropogenic enrichment, organic loadings, receiving water body, sediment.

\section{Introduction}

Wastewaters released by crude oil-processing and petrochemical industries are characterized by the presence of large quantities of crude oil products, polycyclic and aromatic hydrocarbons, phenols, metal derivatives, surface-active substances, sulfides, naphthylenic acids and other chemicals (Suleimanov,1995)). Due to the ineffectiveness of purification systems, wastewaters may become seriously dangerous, leading to the accumulation of toxic products in receiving water bodies with potentially serious consequences on the ecosystem (Beg et. al., 2001; Beg et. al., 2003).

Various studies have shown positive correlation between pollutants from refinery effluents/wastewater and the health of aquatic organisms. Previous observations by Kuehn et. al. (1995) suggested a correlation between contamination of water and sediments with aromatic hydrocarbons from refinery effluents, and compromised fish health. An earlier study demonstrated the accumulation of heavy metals with accompanying histopathology in Oreochromis niloticus exposed to supposedly treated petroleum refinery effluent/wastewater from the Nigerian National Petroleum Corporation, Kaduna (Onwumere and Oladimeji, 1990).

Trace metals in sediments can play a major role in the pollution scheme of a river system. Sediments are repositories for physical debris and sink for contaminants. They can therefore be used to detect pollutants that escape water analysis and also provide information about the critical sites of the river system (Forstner and Wittman, 1983). River sediments are a major potential sink for hydrophobic pollutants in the aquatic environment (Karickhoff et. al., 1979; Means et. al., 1980; Voice \& Weber, 1983).

The analysis of river sediment is a useful method of studying environmental pollution with trace metals (Batley, 1989). The organic matter content of river sediment has been shown to be an important factor in determining the extent of sorption (Means et. al., 1980; Baughman \& Paris, 1981; Karickhoff, 1981; Calmano \& Fôrstner, 1996). It has been assumed that the efficacy of inorganic exchange sites of the clay and its associated organic matter are responsible for the amount and the behaviour of the sorbed substances (Karickhoff \& Brown, 1978) 
The Niger Delta is host to three of Nigeria's four refineries which generate large quantities of effluents/wastewaters daily. These effluents/wastewaters are discharged into natural water bodies after treatment. Though the compositions of these effluents/ wastewater are regulated by various laws, it is not clear whether they comply with the legally accepted toxicant levels for refineries in Nigeria. Furthermore, the impact of these toxicants on the quality of the receiving water body may not have been comprehensibly investigated.

This paper therefore examines the impact of Port Harcourt refinery process wastewater on trace metals in water, sediment and sediment organic matter, in order to determine the physicochemical quality of the receiving water body.

\section{Study Area}

\section{Materials And Methods}

The studied area is in Okrika Local Government Area of Rivers State. It is a riverine and intertidal wetland which lies on the north bank of the Bonny River, about 35 miles $(56 \mathrm{~km})$ upstream from the Bight of Benin in the Eastern Niger Delta of Nigeria. The average elevation of Okrika is 452 meters above sea level. The area is about 905.2 sq. $\mathrm{km}$, and lies on latitude $04^{0} 40^{\prime}$ to $05^{\circ} 00^{\prime} \mathrm{N}$ and longitude $07^{0} 00^{\prime}$ to $07^{0} 15^{\prime} \mathrm{E}$. A maze of rivers and winding creeks intersect it, and within it are, stretches of marshy land having mangrove trees with thickets of tangled roots as the vegetation. Samples were collected from ten locations, the first of which is the Port Harcourt Refinery Wastewater Outfall at Ekerekana Ama (point source), which is about $800 \mathrm{~m}$ from the Port Harcourt Refining Company (PHRC). The remaining nine locations are rivers and creeks around Okrika and are tributaries to Bonny River. The ten sites of sample collection and their relative distances from the discharge point are described in Table 1.

Table 1 Description of sample locations

\begin{tabular}{|c|c|c|}
\hline S/N & Description & Distance from Discharge Point (meters) \\
\hline 1 & Port Harcourt Refinery Process Wastewater Outfall & 800 from the Refinery \\
\hline 2 & Ekerekana Creek & 240.26 \\
\hline 3 & Okochiri Creek & 143.79 \\
\hline 4 & Okari/Okpaku creek & 2817.01 \\
\hline 5 & Okrika/Bonny River & 3155.05 \\
\hline 6 & Ogoloma River & 1719.49 \\
\hline 7 & George Ama Creek & 2631.39 \\
\hline 8 & Ibaka Creek & 3977.84 \\
\hline 9 & Okpoka-Toru or Okpoka River & 4317.50 \\
\hline 10 & Oba Ama Creek & \\
\hline
\end{tabular}

\section{Samples collection, treatment and analysis}

Water samples were collected below the surface film with pre-rinsed 1-litre plastic containers for the analysis of physicochemical parameters and trace metals. Process wastewater samples were collected from the refinery discharge channel in 1-litre plastic containers previously leached with 1:1 HCI and rinsed with distilled water.

Samples for trace metals analyses in water were treated with $2 \mathrm{ml}$ conc. nitric acid prior to storage in order to maintain stable oxidation states of the metals in frozen condition, and also to avoid adsorption of metals on the container, before laboratory analysis (APHA, 1992). Samples were taken two times during each trip to cover at least two of the operational shifts run by PHRC during which changes were assumed to have occurred due to changing logistics. Samples were also collected during mid-ebb periods of low tide to ensure that the influence that was being sought was from the point source, and not the receiving water body. Deep-freezing was used as the method of sample preservation since it allows only the least changes in the sample during storage.

Surface bottom sediment samples for determination of the trace metals and organic matter were collected at low tide by the grab method using Eckman grab sampler from 3 to 4 points at each location (APHA, 1975). The samples were taken in polythene bags previously washed in dilute acid and stored in the laboratory by freezing.

Those for biological oxygen demand (BOD5), chemical oxygen demand (COD) and dissolved oxygen (DO) were collected in $250 \mathrm{ml}$ glass stoppered reagent bottles. The BOD5 samples were carefully filled without trapping in air and the bottles wrapped with dark polythene bags and incubated for 5 days, to exclude all light, the presence of which is capable of producing DO by autotrophes (algae) presumably present in the sample. Dissolved oxygen (DO) samples were fixed up on the spot with Winkler solutions I and II. The COD samples were acidified with tetraoxosulphate (VI) acid (APHA, 1998).

Solvent extraction using ammonium pyrrolidine dithiocarbamate (APDC) and methyl isobutyl ketone (MIBK) was employed for preparation of water samples (including the process wastewater). The water samples for analysis of the major cations were prepared by acid digestion using 1:3:1 mixture of HC1O4, HNO3 and $\mathrm{H} 2 \mathrm{SO} 4$ acids. Trace metals in the process wastewater samples were determined using a procedure of US EPA 
(Suffern et. al., 1981). Each process wastewater sample was filtered using Whatman No.1 filter paper and 500 $\mathrm{ml}$ of the filtrate was measured into $600 \mathrm{ml}$ beaker and evaporated to dryness at $105{ }^{\circ} \mathrm{C}$ in an oven. The

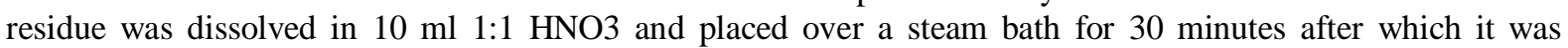
quantitatively filtered into a $25 \mathrm{ml}$ standard flask using Whatman No.1 filter paper. The solution was made up to mark.

Sediment samples were allowed to thaw and air-dried at ambient temperature. They were sieved through $0.5 \mathrm{~mm}$ sieve and $2 \mathrm{~g}$ samples were digested using $25 \mathrm{ml}$ 1:3:1 mixture of $\mathrm{HCIO}_{4}, \mathrm{HNO}_{3}$ and $\mathrm{H}_{2} \mathrm{SO}_{4}$ acids in water bath. To the digest, $10 \mathrm{ml}$ deionized water was added and decanted into $50 \mathrm{ml}$ standard flask and after rinsing, the solution was made up to the mark with deionized water. Buck Scientific atomic absorption spectrophotometer model 200A and air-acetylene flame were used for trace metal analyses, except for mercury which was by the cold vapour method using sodium borohydride $\left(\mathrm{NaBH}_{4}\right)$ in a mercury kit and vapour allowed to go into the AAS instrument without flame.

Accuracy of the methods of analysis for the trace metals was checked using standard seawater sample (CASS-4) for water samples and PACS-2 for the sediment. For each batch of elemental analysis, an intra-run Quality Assurance Standard (1 $\mathrm{mgL}^{-1}$, Multi-Element Standard Solution, Fisher Scientific) was analysed to check for reading deviation and accuracy of every 10 samples (Cantillo and Calder, 1990)

\section{Determination of organic carbon (TOC/TOM)}

For organic carbon, $1 \mathrm{~g}$ dried, sieved sediment was weighed into $250 \mathrm{ml}$ conical flask and digested with $10 \mathrm{ml} 0.5 \mathrm{M} \mathrm{K}_{2} \mathrm{Cr}_{2} \mathrm{O}_{7}$ and $20 \mathrm{ml}$ conc. $\mathrm{H}_{2} \mathrm{SO}_{4}$, for $30 \mathrm{~min}$. (Walkey and Black, 1934). $100 \mathrm{ml}$ deionized water and 3 drops of Ferroin indicator were added and titrated with $0.25 \mathrm{M} \mathrm{FeSO}_{4}$ solution. Organic matter (TOM) was obtained by multiplying organic carbon (TOC) values by 1.724 .

\section{Determination of major cations in water}

Water samples previously acid treated with a 1:3:1 mixture of $\mathrm{HC} \mathrm{O}_{4}, \mathrm{HNO}_{3}$ and $\mathrm{H}_{2} \mathrm{SO}_{4}$ acids and preconcentrated were used to determine major cations in water. Serially diluted mixed standard solutions containing $1.00 \mathrm{mg}$ of the metal ion in $1 \mathrm{ml}$ of the solution were prepared by pipetting appropriate volumes of commercially purchased stock solutions (BDH Chemicals), into a single $250 \mathrm{ml}$ standard flask. The concentrations of each metal ion were read against the standards on a Buck Scientific model 200A atomic absorption spectrophotometer (AAS) equipped with air-acetylene (APHA, 1998).

\section{Other water quality parameters}

Water $\mathrm{pH}$ was determined using a multi parameter HARCH sensor 156, temperature by dipping a mercury in glass thermometer (British standard BS593), salinity using a Hanna membrane millimeter digital scan meter (H8314mmodel), conductivity using a scan conductivity meter, model 1560, total hardness by complexometric titration, Total alkalinity by titration with $\mathrm{HCl}, \mathrm{COD}$ (Titrimetry), $\mathrm{DO}, \mathrm{BOD}_{5}$, by Winkler's method, Total suspended solids and Total dissolved solids by Gravimetry, turbidity, silicate and nitrate by colorimetric method, sulphate by turbidimetric method phosphate by stannous chloride method, calcium and magnesium by EDTA titrimetry, and sodium and potassium by flame photometry (APHA, 1998; ASTM, 2005).

Results

\section{Results And Discussion}

Year average concentrations of trace metals in water (including refinery process wastewater) of Bonny River and creeks around Okrika are presented in Table 2 with results of recovery analysis of standard material, CASS-4 for seawater.

Table 2 Average bimonthly $(\mathrm{n}=6$ ) levels $(\mathrm{ppb})$ of trace metals of the receiving water body (including refinery process wastewater) with their results of recovery analyses of standard water (CASS-4) material

\begin{tabular}{|c|c|c|c|c|}
\hline \multirow{2}{*}{ Metals $(\mathrm{ppb})$} & \multicolumn{4}{|c|}{ Water } \\
\cline { 2 - 5 } & $\begin{array}{c}\text { Receiving Waterbody } \\
\text { Results }(\xi \pm \text { SD) }\end{array}$ & Certified Value & Measured value & Recovery $(\%)$ \\
\hline $\mathrm{Hg}$ & $\mathrm{BDL}$ & - & - & - \\
\hline $\mathrm{Pb}$ & $21.66 \pm 11.65$ & 0.0098 & $0.008 \pm 0.002$ & 79.59 \\
\hline $\mathrm{Ni}$ & $38.84 \pm 32.15$ & 0.314 & $0.304 \pm 0.01$ & 96.82 \\
\hline $\mathrm{V}$ & $0.15 \pm 0.29$ & 0.381 & $0.361 \pm 0.02$ & 94.75 \\
\hline $\mathrm{Cd}$ & $4.45 \pm 2.43$ & 0.026 & $0.02 \pm 0.006$ & 76.92 \\
\hline
\end{tabular}

BDL: Below Detection Limit 
Mercury was below detection limit in the water sample. Results of recovery analysis using Standard Material CASS-4 (seawater) for the trace metals were as follows: cadmium (76.92\%), lead (79.59\%), nickel $(96.82 \%)$, and vanadium $(94.75 \%)$. These could be considered favourable for trace metals analysis in water.

The mean levels of trace metals (ppb) in the refinery process wastewater are also compared with effluent/wastewater limitation guidelines for petroleum refineries and other categories of industrial wastes in Nigeria and this is presented in Table 3.

Table 3 Trace metal levels (ppb) in refinery process wastewater compared with effluent (wastewater) limitation guidelines in Nigeria (NESREA, 2009)

\begin{tabular}{|c|c|c|}
\hline Metal & $\begin{array}{l}\text { Mean levels of trace metals in refinery } \\
\text { process wastewater }\end{array}$ & $\begin{array}{l}\text { Effluent/wastewater limitation guideline for petroleum } \\
\text { refinery and other categories of industries in Nigeria }\end{array}$ \\
\hline $\mathrm{Hg}$ & $\mathrm{BDL}$ & 50 \\
\hline $\mathrm{Pb}$ & $5.90 \pm 6.04$ & $<50$ \\
\hline $\mathrm{Ni}$ & $86.95 \pm 110.39$ & $<1000$ \\
\hline $\mathrm{V}$ & $0.13 \pm 0.21$ & - \\
\hline $\mathrm{Cd}$ & $2.29 \pm 2.37$ & 10 \\
\hline
\end{tabular}

Mercury was also not detectable, but the detectable levels of lead, nickel, vanadium and cadmium were quite below limits set for petroleum and allied wastes in Nigeria. However, the presence of $\mathrm{Pb}, \mathrm{Ni}, \mathrm{V}$ and $\mathrm{Cd}$ in the process wastewater or absence at sometime, is an indication that the process wastewater quality, quantity and composition may change with changing logistics during the routine shifts run by the refinery (UNEP, 1992)

Year average concentrations of trace metals in sediment (including that of refinery process wastewater discharge channel) are presented in Table 4 with results of recovery analysis of standard material, PACS-2 for sediment.

Table 4 Average bimonthly $(\mathrm{n}=6)$ levels $(\mathrm{ppm})$ of trace metals in sediment of the receiving water body with their results of recovery analysis of standard sediment (PACS-2) material

\begin{tabular}{|c|c|c|c|c|}
\hline \multirow[t]{2}{*}{ Metals (ppm) } & \multicolumn{4}{|c|}{ Sediment } \\
\hline & $\begin{array}{c}\text { Receiving Waterbody } \\
\text { Sediment Results }(\xi \pm \text { SD) }\end{array}$ & Certified Value & Measured value & Recovery (\%) \\
\hline $\mathrm{Hg}$ & $0.273 \pm 0.016$ & 90.7 & $86.3 \pm 4.40$ & 94.38 \\
\hline $\mathrm{Pb}$ & $\begin{array}{c}23.218 \pm 13.427 \\
(4.210)^{* * /(40.104) * * *}\end{array}$ & 183 & $174 \pm 9.00$ & 95.08 \\
\hline $\mathrm{Ni}$ & $\begin{array}{c}57.194 \pm 16.929(51.871)^{* * /} \\
(63.125)^{* * *}\end{array}$ & 39.5 & $37.4 \pm 2.1$ & 94.68 \\
\hline $\mathrm{V}^{*}$ & 0.060 & 364 & $340 \pm 24$ & 93.41 \\
\hline $\mathrm{Cd}^{*}$ & 0.130 & 1.000 & $0.770 \pm 0.13$ & 87 \\
\hline \multicolumn{5}{|c|}{ Organic Matter (\%) } \\
\hline TOC & $1.135 \pm 0.401$ & - & - & - \\
\hline TOM & $1.99 \pm 0.703$ & - & - & - \\
\hline
\end{tabular}

TOC: Total Organic Carbon; $\quad$ TOM: Total Organic Matter; $\quad$ *: Only Detectable Values

( )** Values obtained from the Refinery Discharge Channel (Process Wastewater)

( )*** Values at sample location 10 (Oba Ama Creek)

The estimated values of trace metals (ppm, dry weight) and organic matter (\%) in the year were as follows: $\mathrm{Hg}(0.273 \pm 0.016)$; $\mathrm{Pb}(23.218 \pm 13.427)$; $\mathrm{Ni}(57.194 \pm 16.929)$; TOC $(1.135 \pm 0.401)$ and TOM $(1.990 \pm 0.703)$. V and Cd only showed detectable values representing $21.67 \%$ and $31.67 \%$ respectively. Results of recovery analysis using Standard Material PACS-2 (sediment) for the trace metals were as follows: cadmium (87\%), lead $(95.08 \%)$, nickel $(94.68 \%)$, and vanadium $(93.41 \%)$. These are also favourable for trace metals analysis in sediment.

Year average concentrations of physicochemical parameters in water (including refinery process wastewater) of the receiving water body are presented in Table 5.

Table 5 Average bimonthly $(n=6)$ levels of physicochemical parameters of the receiving water body (including refinery process wastewater)

\begin{tabular}{|c|c|c|c|c|c|}
\hline $\mathrm{S} / \mathrm{N}$ & Parameter & $\xi \pm \mathrm{SD}$ & $\mathrm{S} / \mathrm{N}$ & Parameter & $\xi \pm \mathrm{SD}$ \\
\hline 1 & $\mathrm{pH}$ & $7.45 \pm 0.31$ & 11 & TSS $(\mathrm{mg} / \mathrm{L})$ & $9.5 \pm 15.6$ \\
\hline 2 & Temperature $\left({ }^{0} \mathrm{C}\right)$ & $27.2 \pm 0.40$ & 12 & Turbidity $(\mathrm{NTU})$ & $5.0 \pm 11.9$ \\
\hline 3 & TDS $(\mathrm{mg} / \mathrm{L})$ & $26,630 \pm 10,573.9$ & 13 & Silicates $(\mathrm{mg} / \mathrm{L})$ & $2.433 \pm 0.801$ \\
\hline 4 & Salinity $(\mathrm{mg} / \mathrm{L})$ & $13,295.4 \pm 5,263.8$ & 14 & $\mathrm{NO}_{3}{ }^{-}(\mathrm{mg} / \mathrm{L})$ & $0.863 \pm 0.501$ \\
\hline 5 & Conductivity & $51,184.8 \pm 20,274.9$ & 15 & $\mathrm{SO}_{4}{ }^{2-}(\mathrm{mg} / \mathrm{L})$ & $22.4 \pm 3.4$ \\
\hline 6 & $\begin{array}{c}\text { Total Hardness } \\
(\mathrm{Ca}+\mathrm{Mg})-\mathrm{mg} / \mathrm{L}\end{array}$ & $137.80 \pm 49.74$ & 16 & $\mathrm{PO}_{4}{ }^{3-}(\mathrm{mg} / \mathrm{L})$ & $0.392 \pm 0.151$ \\
& Total Alkalinity $(\mathrm{mg} / \mathrm{L})$ & $94.3 \pm 25.4$ & 17 & $\mathrm{Ca}^{2+}(\mathrm{mg} / \mathrm{L})$ & $(2.260 \mathrm{mg} / \mathrm{L})^{*}$ \\
\hline 7 & & & & $48.49 \pm 18.31$ \\
\hline
\end{tabular}


Impact of Discharged Process Wastewater from an Oil Refinery on the Physicochemical Quality of....

\begin{tabular}{|c|c|c|c|c|c|}
\hline 8 & BOD $_{5}(\mathrm{mg} / \mathrm{L})$ & $36.4 \pm 16.7$ & 18 & $\mathrm{Mg}^{2+}(\mathrm{mg} / \mathrm{L})$ & $4.062 \pm 1.022$ \\
\hline 9 & COD $(\mathrm{mg} / \mathrm{L})$ & $44.4 \pm 22.8$ & 19 & $\mathrm{Na}^{+}(\mathrm{mg} / \mathrm{L})$ & $12.123 \pm 1.022$ \\
\hline 10 & DO $(\mathrm{mg} / \mathrm{L})$ & $3.73 \pm 0.29$ & 20 & $\mathrm{~K}^{+}(\mathrm{mg} / \mathrm{L})$ & $9.480 \pm 2.463$ \\
\hline
\end{tabular}

( )*: Value obtained from the Refinery Process Wastewater

The detectable values of physicochemical parameters in water as well as those in the process wastewater from refinery also revealed appreciable levels. Along the line however, with distance increasing, the pattern followed the point and diffuse sources of waste discharge. \})

\section{Discussion}

The sediment trace metals investigated recorded low concentrations. Average percentage organic matter was about $3.32 \%$. This is considered low, and is implicated for the generally low levels of the trace metals in the sediment, since organic matter content of river sediment has been shown in literature to be an important factor in determining the extent of sorption (Karickhoff et. al., 1979; Means et. al., 1980; Voice and Weber, 1983). Low organic matter content is also attributable to low pH. Table 6 shows that all metal levels fall within classes 1 and 2 which is excellent to acceptable in spite of heavy loadings from human and sundry sources. This is in agreement with the findings of Marcus et. al. (2013) in a similar study of Bonny River and creeks around Okrika.

Table 6 Levels of trace metals (ppm, dry weight) in sediment of the receiving water body compared with Netherlands's class limits for sediment with organic matter content $<10 \%$ (EWA, 2005).

\begin{tabular}{|c|c|c|c|c|c|}
\hline & \multicolumn{3}{|c|}{ Class limits in Netherlands } & \multicolumn{2}{c|}{ Class 3 } \\
\hline Metal & $\begin{array}{c}\text { Receiving } \\
\text { Waterbody sediment }\end{array}$ & Class 1 & Class 2 & $1.5-<10$ & $>10$ \\
\hline $\mathrm{Hg}$ & 0.273 & $<0.5$ & $0.5-<1.5$ & - & $>530$ \\
\hline $\mathrm{Pb}$ & 23.218 & $<530$ & - & $45-<210$ & $>210$ \\
\hline $\mathrm{Ni}$ & 57.194 & $<35$ & $35-<90$ & - & - \\
\hline $\mathrm{V}$ & 0.060 & - & - & $7.5->12$ & $>12$ \\
\hline $\mathrm{Cd}$ & 0.130 & $<2$ & $2-<7.5$ & & \\
\hline
\end{tabular}

Notes: Class 1= Excellent; class 2 = Acceptable; class 3 = slightly polluted; class 4 = polluted

However, since the percentage organic matter is $<10 \%$, the results in this study from Table 6 show that the sediment of Bonny River and creeks around Okrika should be of concern with regard to nickel which falls within the slightly polluted class (EWA, 2005). Laboratory studies have shown from environment quality standard (EQS) that nickel has little capacity for accumulation in all the fish studied in salt water in the UK. In uncontaminated water, the range of concentration reported in whole fish (on a wet weight basis) ranged from 0.02 to $2 \mathrm{mgkg}^{-1}$. These values as reported by Hunt and Hedgecott (1992) could be up to 10 times higher in fish from contaminated waters such the waterbody investigated.

Table 7 compares Effluent/wastewater limitation guidelines for petroleum refinery and other categories of industries in Nigeria for discharge into surface water $\left(<40{ }^{0} \mathrm{C}\right.$ within 15 meters of outfall $)$, concentrations of trace metals and physicochemical parameters of the receiving water body, results of Port Harcourt refinery process wastewater analysis, and available data on refinery effluent/wastewater characteristics before and after treatment at the time of the study. The effluent/wastewater characteristic data are means (average values) of several of samples collected and analysed over a period of seven months at the same time this research was carried out.

Table 7 Concentrations of some available physicochemical parameters in Port Harcourt Refinery process wastewater, $\left(\mathrm{mgL}^{-1}\right)$, except $\mathrm{pH}$, conductivity and turbidity; trace metals (ppb) before and after treatment; results of analysis of the receiving waterbody, and effluent/wastewater limitation guidelines

\begin{tabular}{|c|c|c|c|c|c|c|c|}
\hline Parameters & $\mathrm{WW}_{1}$ & $\mathrm{WW}_{2}$ & $\mathrm{WW}_{3}$ & $\mathrm{WW}_{4}$ & $\begin{array}{l}\text { Effluen/wast } \\
\text { ewater from } \\
\text { PHRC }\end{array}$ & $\begin{array}{l}\text { Receiving waterbody } \\
\text { Results }(\xi \pm \text { SD })\end{array}$ & $\begin{array}{l}\text { Effluent/wastewater } \\
\text { limitation guidelines for } \\
\text { petroleum refinery and } \\
\text { other categories of } \\
\text { industries in Nigeria for } \\
\text { discharge into surface } \\
\text { water }\left(<40^{\circ} \mathrm{C} \text { within }\right. \\
15 \text { meters of outfall })\end{array}$ \\
\hline $\mathrm{pH}$ & 7.93 & 8.3 & 6.03 & 8.47 & 6.87 & $7.45 \pm 0.31$ & $6-9$ \\
\hline Temperature & - & - & - & - & - & $27.2 \pm 0.40$ & \\
\hline Conductivity $\left(\right.$ ųscm $\left.^{-1}\right)$ & 1179.3 & 1146 & 774 & 995.2 & 631.3 & $51,184.8 \pm 20,274.9$ & - \\
\hline $\begin{array}{l}\text { Total Hardness } \\
(\mathrm{Ca}+\mathrm{Mg})\end{array}$ & - & - & - & - & - & $137.80 \pm 49.74$ & - \\
\hline
\end{tabular}


Impact of Discharged Process Wastewater from an Oil Refinery on the Physicochemical Quality of....

\begin{tabular}{|c|c|c|c|c|c|c|c|}
\hline Total Alkalinity & - & - & - & - & - & $94.3 \pm 25.4$ & - \\
\hline $\mathrm{BOD}_{5}$ & 75.3 & 216 & 22.08 & 5.28 & 56.4 & $36.4 \pm 16.7$ & 30 \\
\hline COD & 155.3 & 232.1 & 26.68 & 91.76 & 70.0 & $44.4 \pm 22.8$ & - \\
\hline DO & 1.00 & 2.00 & 1.00 & 0.75 & 3.32 & $3.73 \pm 0.29$ & - \\
\hline Turbidity (NTU) & 15 & 18 & 12 & 16 & 13.0 & $5.0 \pm 11.9$ & - \\
\hline Silicates & - & - & - & - & - & $2.433 \pm 0.801$ & - \\
\hline Nitrate $\left(\mathrm{NO}_{3}{ }^{-}\right)$ & 1.53 & 1.91 & 1.64 & 0.754 & 0.004 & $0.863 \pm 0.501$ & 20 \\
\hline Phosphate $\left(\mathrm{PO}_{4}{ }^{3-}\right)$ & 1.11 & 15.4 & 6.81 & 6.21 & 2.260 & $0.392 \pm 0.151$ & 5.0 \\
\hline Salinity & 19.52 & 18.62 & 16.92 & 13.1 & 180.0 & $13,295.4 \pm 5,263.8$ & - \\
\hline TSS & 25 & 30 & 15 & 20 & 12.1 & $9.5 \pm 15.6$ & 30 \\
\hline Phenols & 90 & 69.112 & 1.84 & 11.60 & - & - & 0.2 \\
\hline Oil and grease & 26.42 & 12.48 & 4.27 & 7.52 & - & - & 10 \\
\hline Sulphate $\left(\mathrm{SO}_{4}{ }^{2-}\right)$ & 13.91 & 30.31 & 39.08 & 30.74 & 13.9 & $22.4 \pm 3.4$ & 500 \\
\hline TDS & 383.6 & 335.4 & 209.23 & 390.6 & 359.2 & $26,630 \pm 10,573.9$ & 2000 \\
\hline Calcium $\left(\mathrm{Ca}^{2+}\right)$ & - & - & - & - & - & $48.49 \pm 18.31$ & 200 \\
\hline Magnesium $\left(\mathrm{Mg}^{2+}\right)$ & - & - & - & - & - & $4.062 \pm 1.022$ & 200 \\
\hline Sodium $\left(\mathrm{Na}^{+}\right)$ & - & - & - & - & - & $12.123 \pm 1.022$ & - \\
\hline Potassium $\left(\mathrm{K}^{+}\right)$ & - & - & - & - & - & $9.480 \pm 2.463$ & - \\
\hline Zinc (Zn) & 0.186 & 0.187 & 0.11 & 0.11 & - & - & 0.1 \\
\hline Iron $(\mathrm{Fe})$ & 0.214 & 0.297 & 0.203 & 0.241 & - & - & 20 \\
\hline Copper $(\mathrm{Cu})$ & $<0.001$ & $<0.001$ & $<0.001$ & $<0.001$ & - & - & $<<$ i.0 \\
\hline Ammonia $(\mathrm{N})$ & 22.35 & 26.01 & 13.52 & 8.52 & - & - & 0.01 \\
\hline Sulphide & $<0.01$ & $<0.01$ & $<0.01$ & $<0.01$ & - & - & 0.2 \\
\hline Cyanide & $<0.01$ & $<0.01$ & $<0.01$ & $<0.01$ & - & - & 0.1 \\
\hline Chromium (Cr) & 0 & 0 & 0 & 0 & - & - & $<0.1$ \\
\hline
\end{tabular}

$\mathrm{WW}_{1}$ : Process wastewater, $\mathrm{WW}_{2}$ : Raw wastewater, $\mathrm{WW}_{3}$ : Treated wastewater, $\mathrm{WW}_{4}$ : Observation pond wastewater.

Untreated refinery effluents generated by the refinery include the process wastewater $\left(\mathrm{WW}_{1}\right)$ derived from the refining process, and the raw wastewater $\left(\mathrm{WW}_{2}\right)$ which is a combination of $\mathrm{WW}_{1}$ and sewage that is channeled to the rotary bio-disk for treatment. The treated effluents include treated wastewater $\left(\mathrm{WW}_{3}\right)$ which is refinery effluent/wastewater that has undergone both chemical and biological treatment to eliminate or reduce waste contents to acceptable levels, and the observation pond wastewater $\left(\mathrm{WW}_{4}\right)$ which is a combination of treated wastewater and non-processed wastewater stream, and is likely to have both acute and chronic effects on the marine organisms, especially the bottom feeders within the impacted areas.

One on one interview with local fishermen revealed with physical evidence that the area around the point of discharge of the process wastewater is devoid of fishes and hence fishing as well as recreational activities (such as swimming, canoe race, etc) that hitherto characterized the area are not carried out there anymore for fear of being exposed to health risk. Unpublished data also show a dramatic reduction in the number of viable microorganisms found in both water and sediment at the point of impact. This has resulted in the absence of sediment and filter feeders like periwinkles and oysters respectively that are used to prepare local delicacies by the indigenes.

The data in the table 7 comprehensively tell where and what concentration is highest or lowest for each of the parameters in relation to what has been obtained in this study and what the process wastewater limitation guidelines should be. The guidelines were taken from the National Environmental Standards and Regulation Enforcement Agency (2009). However, lead, nickel which relate to this study were not detected, detection limit being $<0.001 \mathrm{mgL}^{-1}$ in the refinery wastewater before and after treatment as at the time the data in table 7 was filed. It is observed however, from the values of other pollution indicators such as DO, BOD, turbidity, phosphate, salinity and TDS in this study that, the water quality at the point of the process wastewater discharge and beyond may be considered to have been influenced by an improperly treated type process wastewater that was in need of further treatment action in order to reduce the contaminant concentrations to acceptable levels.

The level of the metals in the receiving water body (Bonny River and creeks around Okrika) are generally low (Table 2), and this may be attributable in part to self purification capacity of the system (EPA, 1976), and also, to its brackish condition occasioned probably by salt water intrusions from sea water which may increases the volatilities of many elements that could promote analyte loss during the pyrolysis step (Haavard, 2003). The levels of $\mathrm{Pb}$ and Cd however, slightly exceeded US EPA limits (<1.0-7.0) ppb for Pb and $<0.2-2.8 \mathrm{ppb}$ ) for marine/brackish and freshwater for marine/brackish and freshwater (USA EPA, 2000).

Results of the trace metals in refinery process wastewater were: $\mathrm{Pb}(5.90 \pm 6.04), \mathrm{Ni}(86.95 \pm 110.39)$, $\mathrm{V}(0.13 \pm 0.21)$ and $\mathrm{Cd}(2.29 \pm 2.37)$. The Effluent/wastewater limitation guideline for petroleum refinery and other categories of industries in Nigeria (NESREA, 2009) stipulates <50ppb for $\mathrm{Pb},<1000 \mathrm{ppb}$ for $\mathrm{Ni}$ and $10 \mathrm{ppb}$ for $\mathrm{Cd}$. The detectable levels of lead, nickel, vanadium and cadmium were quite below limits set for petroleum and allied industrial wastes in Nigeria. 
The levels of $\mathrm{Ni}$ and $\mathrm{Pb}$ are appreciable both in the process wastewater discharge channel sediment and those of other sampling stations. The pattern is in line with point and diffuse sources of waste discharge whereby concentration of pollutants in the receiving water bodies is initially high, decreasing as the distance from the point source increases for some of the locations within the Ekerekana creeks (DPR, 2002). Superimposed on this however, is an inverse relationship with an irregular pattern where even location ten at Oba Ama, which is farthest at a distance of about $4317.50 \mathrm{~m}$, recorded the values, $40.104 \mathrm{ppm}$ for lead and $63.125 \mathrm{ppm}$ for nickel, which formed part of their mean values of 23.218 \pm 13.427 and $57.194 \pm 16.929$ respectively (Table 4). This, again, suggests that these metals may have had their way into the sediment by activities other than those of the refinery that may be considered diffuse.

Temperature and dissolved oxygen play vital roles in the rate of chemical reaction and the nature of biological activities, thus governing the assimilative capacity of aquatic systems. Year average temperature in the present study was about $27{ }^{\circ} \mathrm{C}$, while, the upper limit for survival fish is $36{ }^{\circ} \mathrm{C}$. The low temperature could be attributed to over-hanging macrophytes, a dominant feature of the studied area which prevents sunlight on the water (King and Nkanta, 1991).

Average DO was $3.73 \mathrm{mg} / \mathrm{L}$. This condition does not suggest pollution considering the fact that in worst conditions such as in warm water conditions, DO concentrations range from 4-1 mg/L (MPMMG, 1998). Fish needs at least $2 \mathrm{mg} / \mathrm{L}$ DO concentration to survive (Barnes et. al., 1998). In waters where there is little mixing and in organically enriched systems, depletion of dissolved oxygen typically occurs in the bottom layer because there is little or no photosynthetic activities or little or no mixing with oxygen- rich surface layer. This may lead to reducing conditions which can remobilize trace metals (Forstner and Wittman, 1979). However, average value of $3.73 \mathrm{mg} / \mathrm{L}$ for DO in this study shows much depletion may have occurred, caused by oxygen consuming chemicals from the refinery with BOD and COD levels being $36.4 \mathrm{ppm}$ and 44.4 ppm respectively.

The levels of BOD5 and COD are quite considerable and could be ascribed to organic contamination entering the system from municipal and industrial effluents due to urban life and many industrial establishments. These organic materials eventually get broken down by bacteria, which require oxygen for the decomposition process, leading to depletion of DO, hence the low DO content of the water. This conforms to reports by Quinby-Hunt et. al. (1986) that a low DO indicates a high COD and BOD5 values.

Water hardness, alkalinity, pH (associated with buffering capacity) and nutrients such as nitrates, carbonates, and phosphates, are some of the other important chemical characteristics governing the nature and quantity of wastes in the different phases of a natural aquatic system (EPA,1976). These chemical parameters, because of synergistic and antagonist interactions together in part, determine the general physiochemical condition prevailing in the water system, and in this way, play significant roles in the distribution of pollutants such as the trace metals between the water column, sediment and organism. In Table 5, the value of phosphate, $\mathrm{PO}_{4}{ }^{3-}(2.260 \mathrm{mg} / \mathrm{L})$, which is particularly highest in the refinery process wastewater, implicates the Port Harcourt refinery as an important source of this anion. In estuaries and coastal waters, apart from stimulating productivity of phytoplankton along with nitrogen, in areas where primary productivity is not limited by high availability, high concentrations are associated with the effects of eutrophicaton, a like consequence of prolonged exposure. (Scott et. al., 1999).

It had also been reported of Southampton water that mussel foiling (growth of unwanted organisms in cooing water systems, a well documented source of contaminants from oil refinery operations) resulted from the contamination of phosphates, nitrates and ammonium (Reomerial, 1973)

\section{Conclusion}

The receiving water body and its environ of process wastewater from the Port Harcourt Refinery has been shown to result in appreciable concentrations of chemical contaminants (including trace metals) in the water and sediment. The chemical contaminants come from a direct input from industrial and domestic wastes and indirectly via tributary rivers and runoff waters. This suggests that the metals and other contaminants may have had their way into the system by activities other than those of the refinery which may be considered diffuse. The long term impact of refinery process wastewater amidst other activities in the studied area is not really known, it is believed however, that the complex combination of toxic substances that are simultaneously present in refinery wastes may act synergistically and therefore impose a higher toxicity burden on the entire ecosystem than may be predicted in laboratory studies on individual toxicants (Mizell and Romig, 1997).

\section{References}

[1]. APHA (1975) American Public Health Authority Standard methods $14^{\text {th }}$ edition. Assoc. Wat. Poll. Fed. (APHA-AWWA-WPCF). Washington D.C USA.

[2]. APHA (1998) Standard methods for the examination of water and wastewater $20^{\text {th }}$ edition. American Public Health Association, American Water Works Association and Water Environment Federation (APHA-AWWA-WEF), Published by the American Public Health Association, Washington D.C.

[3]. ASTM (2005) Annual book for ASTM standards. American Society for Testing Materials, p.285. 
[4]. Barnes, K.H., Meyer, J.L and Freeman, B.J. (1998) Sedimentation and Georgia's fishes: An analysis of existing information and future research. 1997 Georgia Water Resources. Conference, March 20-22, 1997, University of Georgia, Athens, Georgia.

[5]. Batley, G.E. 1989. Trace Metal Speciation: Analytical Methods and Problems. CRC Press, Boca Raton, Florida.

[6]. Baughman G. L. \& Paris, D. F. (1981) Microbial bioconcentration of organic pollutants from aquatic systems - a critical review. Critical Reviews in Microbiology 8, 205-228.

[7]. Beg, M.U., Al-Muzaini, S., Saeed, T., Jacob, P.G., Beg, K.R., Al-Bahloul, M., Al-Matrouk, K., Al-Obaid, T. \& Kurian, A. (2001) Chemical contamination and toxicity of sediment from a coastal area receiving industrial effluents Kuwait. - Archives of Environmental Contamination and Toxicology 41: 289-297.

[8]. Beg, M.U., Saeed, T., Al-Muzaini, S., Beg, K.R. \& Al-Bahloul, M. (2003) Distribution of petroleum hydrocarbon in sediment from coastal area receiving industrial effluents in Kuwait. - Ecotoxicol Environ Saf. 54: 47-55.

[9]. Benson, B.U. and Etesin, U.M. (2008) Metal contamination of surface water, sediment and Tympanotus fiscatus var. radular of Iko River and environmental impact due to Utapete gas flare station, Nigeria. Environmentalist 28: 195-202.

[10]. Calmano, W. \& Fôrstner, U. (1996) Sediments and Toxic Substances. Springer, Berlin.

[11]. Cantillo, A. and Calder, J (1990) Reference material for marine science. Fresenius Journal of Analytical Chemistry 338:380-382.

[12]. Chindah, A.C., Braide, S.A., Sibeudu, O.C. (2004) Distribution of hydrocarbons and heavy metals in sediment and a crustacean shrimps-Penaeus notialis from the Bonny/New Calabar River Estuary, Niger Delta. A JEAM-RAGEF 9:1-17

[13]. Craft., C.B., Seneca, E.D and Broome, S.W. (1991) Loss in ignition and Kjeldahl digestion for estimating organic carbon and total nitrogen in estuarine marsh soils: calibration with dry combustion. Estuaries 14: 175-179.

[14]. DPR (2002) Environmental guidelines and standards for the Petroleum Industry in Nigeria (EGASPIN). Issued by the Department of Petroleum Resources, Lagos, 1991, $2^{\text {nd }}$ Ed., pp 3-17; 43-63; 126; 230-237.

[15]. EPA (1976) Quality criteria for water, US EPA, 440/9-76-023; Environmental Protection Agency, Washington DC.

[16]. EWA (2005) Official Publication of the European Water Association (EWA). Netherlands. p 2.

[17]. Forstner, U. and Wittman, G.T.U. 1979, Metal pollutioin in the aquatic environment, New York, Spingler-Verlag, 99-118.

[18]. Forstner, U and Wittmann, G.T.W. (1983) Metal Pollution in the aquatic environment, $2^{\text {nd }}$ edition, Springer Verlag Publishers, New York. pp 18-49.

[19]. Haavard, H. (2003) Trace elements determination AAS. Norwegian Institute for Water Research, HORIZONTAL-20. p 10.

[20]. Hunt, S. and Hedgecott, S. (1992) Revised environmental quality standards for nickel in water. WRc report to the Department of the Environment DoE 2685/1.

[21]. Karickhoff, S. W. \& Brown, D. S. (1978) Paraquat sorption as a function of particle size in natural sediments. J.Environ. Qual. 7: 246-252.

[22]. Karickhoff, S. W., Brown, D. S. \& Scott, T. A. (1979) Sorption of hydrophobic pollutants on natural sediments. Wat.Res. 13, 241248 .

[23]. Karickhoff, S. W. (1981) Semi-empirical estimation of sorption of hydrophobic pollutants on natural sediments andsoils. Chemosphere 10: 833-846.

[24]. King, R.P and Nkanta, N.A. (1991) The status and seasonality in the physicochemical hydrology of a Nigerian rain forest pond. The Japanese Jour. of Limnology 52:1-12.

[25]. Kuehn, R.L., Berlin, K.D., Hawkins, W.E. \& Ostrander, G.K. (1995) Relationships among petroleum refining, water and sediment contamination, and fish health. - Journal of Toxicology and Environmental Health 46: 101-116.

[26]. McConchie, D.M., Mann, A.W., Lintern, M.J., Longman, D., Talbot, V. and Gabelish, A.(1988) Heavy metals in marine biota, sediment and waters from the Shark Bay area,Western Australia, Journal of Coastal research 4:37-58.

[27]. Marcus A. C., Okoye C. O. B. and Ibeto C. N. (2013) Organic matter and trace metals levels in sediment of bonny river and creeks around Okrika in Rivers State, Nigeria. International Journal of Physical Sciences 8 (15): 652-656.

[28]. Means, J. C, Wood, S. G., Hassett, J. J. \& Banwart, W. L. (1980) Sorption of polynuclear aromatic hydrocarbons by sediments and soils. Environ. Sci. \& Technol. 14, 1524-1528.

[29]. Mizell, M and Romig E.S. (1997) The aquatic vertebrate embryo, a sentinel for toxins: Zebra fish embryo, dichorionation and perivitelline space microinjection. International Journal of Developmental Biology 41:411-423.

[30]. MPMMG (Marine Pollution Monitoring Management Group). (1998) National monitoring programme survey of the quality of UK coastal waters Marine pollution monitoring management Group, Aberdeen, ISBN O9532838 36.

[31]. NESREA (2009) National environment (wetlands, rivers banks and lake shores protection) regulation. Published by National Environmental Standards and Regulations Enforcement Agency (Establishment) Act, 2007, No.58, Vol.96

[32]. Okoye, B.C.O. (1989). Heavy metals in the Lagos lagoon. Ph.D. Thesis, Department of Chemistry. Obafemi Awolowo University, Ile-Ife, Nigeria.

[33]. Onwumere, B.G. \& Oladimeji, A.A. (1990) Accumulation of metals and histopathology in Oreochromis niloticus exposed to treated NNPC Kaduna (Nigeria) petroleum refinery effluent-Ecotoxicology and Environmental Safety 19: 123-134.

[34]. Quinby-Hunt, M.S., Lughlin, M.D. and Quintanilba, A.T. (1986) Instrumentation for environmental monitoring,2nd ed., John Wiley and Sons, New York. pp155-184; 338-374.

[35]. Reomerial, M.G. (1973) Focus on Marine ecology. Chem. Brit. 9 (4):103-105.

[36]. Scott, C.R., Hemingway, K.L., Elliot, M., De Jonge, V.N., Pettwick, J.S., Malcolm, S. and Wilkmson, M. (1999) Impact of nutrients in estuaries- Phase 2 Report to English Nature and the Environment Agency.

[37]. Suffern, J.S., Fitzgerald, C.M. and Szluha, A.T. (1981) Trace metal concentrations in oxidation pond. Journal of Water Control Federation 53:1599-1607.

[38]. Suleimanov, R.A. (1995) Conditions of waste fluid accumulation at petrochemical and processing enterprises and prevention of their harm to water bodies. - Meditsina Truda i Promyshlennaia Ekologiia 12: 31-36.

[39]. United Nation Environmental Protection (UNEP)-Industry and environmental overview series (1992) Environmental management practices in Oil refineries: United nation environmental Programm. pp 8-52.

[40]. US EPA (2000) Nation water quality inventory: 1998 Report to congrdess.www.epa.gov/305b/98report. Cast updated October 5, 2000 .

[41]. Voice, T. C. \& Weber, W. J. (1983) Sorption of hydrophobic compounds by sediments, soils and suspended solids. Wat. Res. 17, 1433-1441.

[42]. Walkey, A and Black, L.A. (1934) An examination of the Dagtjareff method for determination of soil organic matter and a proposed modification of the chromic acid titration method. Soil Science 37:29-38. 